CLINICAL STUDY

\title{
$\beta$-cell function and metabolic control in latent autoimmune diabetes in adults with early insulin versus conventional treatment: a 3-year follow-up
}

\author{
Maria Thunander ${ }^{1,2}$, Hlin Thorgeirsson ${ }^{1}$, Carina Törn ${ }^{3}$, Christer Petersson ${ }^{4,5}$ and Mona Landin-Olsson ${ }^{1}$ \\ ${ }^{1}$ Department of Endocrinology and Diabetology, Lund University Hospital, Lund, Sweden, ${ }^{2}$ Department of Internal Medicine, Central Hospital, S-351 85 \\ Växjö, Kronoberg, Sweden, ${ }^{3}$ Department of Clinical Sciences, Lund University, Malmö, Sweden, ${ }^{4}$ Primary Care, Växjö, Kronoberg, Sweden and \\ ${ }^{5}$ RED County Council, Växjö, Kronoberg, Sweden \\ (Correspondence should be addressed to M Thunander at Department of Internal Medicine, Central Hospital; Email: maria.thunander@Itkronoberg.se)
}

\begin{abstract}
Objectives: The optimal treatment of latent autoimmune diabetes in adults (LADA) is not established. We explored whether early insulin treatment, which has shown beneficial effects in rodents and in human pilot studies, would result in better preservation of $\beta$-cell function or metabolic control, compared with conventional treatment.

Subjects and methods: Glucagon-stimulated C-peptide and HbAlc were evaluated at baseline and after 12, 24 and 36 months in 37 patients recently diagnosed with diabetes, aged $\geq 30$ years, non-insulinrequiring and GADAb and/or ICA positive. Twenty patients received early insulin and 17 received conventional treatment (diet \pm oral hypoglycaemic agents (OHA), metformin, some and/or sulfonylurea) and insulin when necessary.

Results: Level of metabolic control, HbAlc, was preserved in the early insulin treated, while it significantly deteriorated in the conventionally treated. There was no significant difference between the groups in C-peptide after 12, 24 or 36 months, or in the decline of C-peptide. Only baseline C-peptide predicted a C-peptide of $\geq 0.5 \mathrm{nmol} / \mathrm{l}$ at 36 months. Gender, body mass index, antibody titres or HbAlc did not influence the levels of C-peptide or HbAlc at baseline or end-of-study, or the decline in C-peptide. Among the diet \pm OHA-treated, 5/17 (30\%) developed insulin dependency during the follow-up. No major hypoglycaemic events occurred.

Conclusions: Early insulin treatment in LADA leads to better preservation of metabolic control and was safe. Superior preservation of C-peptide could not be significantly demonstrated. Only baseline level of C-peptide significantly influenced C-peptide level after 3 years. Further studies exploring the best treatment in LADA are warranted.
\end{abstract}

European Journal of Endocrinology $164239-245$

\section{Introduction}

Most adults with autoimmune diabetes non-insulinrequiring at diagnosis become so within $3-6$ years $(1,2)$. The optimal treatment for this second largest group of patients with diabetes is still unknown (3-7). Adult patients with autoimmune diabetes usually have larger remaining $\beta$-cell mass at diagnosis and many develop $\beta$-cell destruction more slowly. Latent autoimmune diabetes in adults (LADA) is therefore a suitable group for evaluating new therapies in autoimmune diabetes and may also serve as a model for intervention in classical type 1 diabetes (3, 4, 6-9).

The incidence of autoimmune diabetes is about equal in almost all age groups $(10,11)$. Abrupt onset, often with ketoacidosis, is most frequent during childhood, a more modest onset is more frequent in adolescents and younger adults, and among adults and elders a slowly progressive onset, termed LADA, is frequent (3, 4, 11, 12). Classical type 1 diabetes and LADA patients often have normal C-peptide levels at diagnosis, but further progressive decline occurs after onset, and insulin dependency occurs almost inevitably $(3,4,8,9,13)$.

Most trials in early type 1 diabetes have been performed in children, whose remaining $\beta$-cell mass is limited, and short-term evaluation of intervention may be difficult also due to not infrequently occurring remission periods $(14,15)$. No therapy has yet been demonstrated to promote long-term insulin independency $(3,5,7,16)$. Rodent studies have demonstrated potential positive effects of insulin treatment $(17,18)$. A pilot study of small doses of insulin versus sulphonylurea (SU) to ten ICA-positive patients with slowly progressive $\beta$-cell failure favoured insulin for the preservation of C-peptide (19). C-peptide is the outcome 
measure of choice of $\beta$-cell function in trials of autoimmune diabetes (20). Even modest preservation of $\beta$-cell function has been demonstrated to have positive effects on the frequency of hypoglycaemic events, and on the prevalence of retinopathy (21). Connection between glycaemic control and development of complications is well established (21-23).

\section{Objective}

To investigate the effect of early insulin treatment in LADA patients, for 3 years, on residual $\beta$-cell function and metabolic control, compared with a group initially treated with diet and/or oral hypoglycaemic agents (OHA).

\section{Subjects and methods}

Adults, aged $\geq 30$ years, diagnosed with diabetes in Lund and Kronoberg counties in Southern Sweden, non-insulin-requiring at diagnosis and positive to at least one of GADAbs and/or ICAs were eligible for participation. Two thirds had to be excluded due to mental conditions or severe physical illness, but also unwillingness to risk the early start of insulin injections. The majority of the patients were randomised into two groups, in blocks of eight, by pre-prepared closed envelopes kept at the two hospital policlinics. However complete strict randomisation was not possible, as some patients refused randomisation to possible insulin treatment before it was unavoidable. They were referred to the control group. There were 20 patients in the intervention group (I), treated with insulin from baseline, starting with 2-6 units intermediate-acting insulin at night; and 17 patients in the control group (C) who received regular treatment with diet $\pm \mathrm{OHA}$, mostly metformin, and some SU $(5 / 17 ; 30 \%)$. For both the groups, goals for glucose levels were in accordance with general guidelines (fasting plasma glucose (FPG) 4.5-7, preprandial PG 5-7 and postprandial PG 6-9 mmol/l). Decisions to increase treatment in doses, number of doses and addition of OHAs or insulin were at the discretion of the treating physician. If two doses/day of intermediate-acting insulin or mix-insulin were not satisfactory, doses of direct or rapid-acting insulin before meals were added, resulting in 1-4 doses/day. Patients were either treated at the hospital polyclinics or continued at their healthcare centre.

Residual $\beta$-cell function was evaluated by glucagonstimulated C-peptide. Glucagon-stimulation tests were performed at baseline and after 12, 24 and 36 months during annual policlinic visits at the two research clinics. After an overnight fast, C-peptide was determined before and $6 \mathrm{~min}$ after i.v. injection of $1 \mathrm{mg}$ glucagon (24). C-peptide was analysed by commercial RIA (MD315, Euro-Diagnostica AB,
Malmö, Sweden), total variation (sum of intra-and inter-assay variations) 7\%, reference range $0.25-1.0 \mathrm{nmol} / \mathrm{l}$, detection limit $0.13 \mathrm{nmol} / \mathrm{l}$. C-peptide level, to reflect a preserved normal $\beta$-cell function, was arbitrarily set at $0.5 \mathrm{nmol} / \mathrm{l}$. ICAs were analysed with immunofluorescence assay, with detection limit 9 JDF-U, sensitivity $100 \%$ and specificity $88 \%$. GADabs were analysed with radioimmuno-precipitation with lower reference limit at an index of 0.08 , corresponding to $21 \mathrm{WHO}-\mathrm{U} / \mathrm{ml}$, sensitivity $70 \%$ and specificity $100 \%$. IA-2A were analysed with ELISA. All analyses were standardised according to the Diabetes Antibody Standardization Program $(25,26)$. Metabolic control was assessed by HbAlc (Mono-S), and values were converted to DCCT standard (27).

Regarding the metabolic syndrome, complete information was available regarding only body mass index (BMI) and prevalence of hypertension, defined as blood pressure $>140 / 80 \mathrm{mmHg}$ at the baseline visit, or taking antihypertensive medication.

All subjects provided informed consent. The study was approved by the ethical committee of Lund University. The study is registered in ClinicalTrials.gov Identifier: NCT01109927.

\section{Statistical analyses}

Analyses were carried out according to intentionto-treat. For comparisons between the groups, Student's $t$-test, $\chi^{2}$ or Fisher's exact test and the Mann-Whitney $U$ test were performed where appropriate. C-peptide and HbAlc at baseline and after 12, 24, and 36 months were analysed with repeated measures ANOVA using time as covariate; for three-group analyses, ANOVA with Bonferroni correction was performed where appropriate. Risk factors and relations were analysed in several models with simple, multiple, linear and logistic regressions (forward stepwise, Wald). All tests were two-sided, $P<0.05$ was considered significant. SPSS software, version 17.0 (Chicago, IL, USA), was used.

\section{Results}

For the baseline characteristics of the groups, see Table 1. There were no significant gender differences in the whole study, except that in the control group there were only men with hypertension $(P=0.03)$. Most subjects were overweight since both the I and $\mathrm{C}$ groups had mean BMI $\geq 27 \mathrm{~kg} / \mathrm{m}^{2}$. Median duration of diabetes at inclusion in the study was 5.0 (quartiles 3.0-9.0) months. In both the groups, $90 \%$ of the patients, $18 / 20$ in I and 15/17 in C, completed 36 months of follow-up. Four patients withdrew consent. Among the conventionally treated (C), 30\% (5/17) started insulin treatment due to clinical necessity within 6-6-1218-24-30 months. 
Table 1 Baseline characteristics of the LADA groups. Values are mean \pm s.D. (range), except duration, which is median.

\begin{tabular}{lllll}
\hline & All & Intervention group & Control group & $\boldsymbol{P}$ value \\
\hline Age (years) & $54.1 \pm 14.9(30-80)$ & $51.0 \pm 14.3(30-75)$ & $57.8 \pm 15.1(31-80)$ & $\mathrm{NS}$ \\
Gender (men, \%) & 51.4 & 45.0 & 58.8 & $\mathrm{NS}$ \\
Diabetes duration (months) & $5.0(1-24)$ & $6.0(1.5-24)$ & $5.0(1-22)$ & $\mathrm{NS}$ \\
BMl $\left(\mathrm{kg} / \mathrm{m}^{2}\right.$ ) & $27.8 \pm 6.2(19.4-49.5)$ & $27.0 \pm 6.9(19.4-49.5)$ & $28.7 \pm 5.3(22.0-42.2)$ & $\mathrm{NS}$ \\
C-peptide (stimulated, nmol/l) & $1.45 \pm 0.83(0.29-3.4)$ & $1.2 \pm 0.73(0.29-3.0)$ & $1.7 \pm 0.86(0.65-3.4)$ & 0.03 \\
HbAlc (\%) & $7.2 \pm 1.3(5.2-10.1)$ & $7.3 \pm 1.3(5.6-10.1)$ & $7.0 \pm 1.3(5.2-9.5)$ & $\mathrm{NS}$ \\
Titre GADA (index, ref $<0.08)$ & $0.78 \pm 0.43(0.6-1.6)$ & $0.78 \pm 0.39(0.06-1.6)$ & $0.78 \pm 0.48(0.12-1.6)$ & $\mathrm{NS}$ \\
Titre ICA (JDF-U) & $50.2 \pm 89(0.0-449)$ & $29.4 \pm 40.5$ & $72.4 \pm 118$ & $\mathrm{NS}$ \\
Hypertension $(\%)$ & 39.4 & 41.2 & 37.5 & $\mathrm{NS}$ \\
BMl $>25 \mathrm{~kg} / \mathrm{m}^{2}(\%)$ & 42.0 & 43.5 & 37.5 & $\mathrm{NS}$ \\
Hypertension $+\mathrm{BMI}>25 \mathrm{~kg} / \mathrm{m}^{2}(\%)$ & 32.4 & 29.4 & 37.5 & $\mathrm{NS}$ \\
\hline
\end{tabular}

\section{$\beta$-Cell function}

For the levels of glucagon-stimulated C-peptide, see Table 2 and Fig. 1. C-peptide levels were unchanged for four patients, increased by mean $0.73( \pm 0.5) \mathrm{nmol} / \mathrm{l}$ for six and declined in all others after 36 months. Mean glucagon-stimulated C-peptide decreased significantly in both the groups during the 36 months $(P<0.0001)$. There was a significant time trend for the decrease in C-peptide of $0.17 \mathrm{nmol} / \mathrm{l}$ per year $(P=0.03)$ over 36 months without any significant difference between the groups. In repeated measures, ANOVA with time as covariate, that analyses the changes in C-peptide over time with the levels at baseline taken into account, no differences could be found regarding mean-stimulated C-peptide at any time point, although with the MannWhitney $U$ test the difference in C-peptide at baseline (Cp0) was significant, $P=0.03$. There were large variations in C-peptide levels between different individuals, at all time points, within both the groups $(P<0.0001)$, explaining all the variation between them (Fig. 1A and B). Cp0 explained $43 \%$ of level of C-peptide at 36 months (Cp36), $R^{2} 0.43(P<0.0001)$. Furthermore, age was the only other factor that had a weak and non-significant influence on $\mathrm{Cp} 36$, explaining about $5 \%$ of $\mathrm{Cp} 36, R^{2} 0.049(P=0.2)$. The influence of age was eliminated when included in a multiple regression model. Gender, baseline or end-of-study values of BMI, titres of GADAb or ICA, HbAlc or diabetes duration before the study start did not influence C-peptide at end-of-study. There was no significant difference in the proportion of patients with a $\mathrm{Cp} 36 \geq 0.5 \mathrm{nmol} / \mathrm{l}$. It was $86 \%(13 / 15)$ in $\mathrm{C}$, and $61 \%(11 / 18)$ in $\mathrm{I}(P=0.13)$.

The odds ratio (OR) for having a $\mathrm{Cp} 36 \geq 0.5 \mathrm{nmol} / \mathrm{l}$ was 2.4 for every increase in $\mathrm{Cp0}$ with $0.10 \mathrm{nmol} / \mathrm{l}$ $(P=0.02)$, and 1.06 for each increase in baseline age by 1 year $(P=0.03)$. If corrected for $\mathrm{CpO}$ and age, the two factors found to have any influence on $\mathrm{Cp} 36$, the insulin treated had a non-significant OR of $2.5(0.04-184)$ of having a Cp36 of $\geq 0.5 \mathrm{nmol} / \mathrm{l}$.

The results of levels of fasting C-peptide (FCP), when comparing the two treatment groups (data not shown), were in accordance with the described results of stimulated C-peptide.

\section{Metabolic control}

Among the controls, the level of HbAlc had increased significantly at 36 months from $7.0( \pm 1.3) \%$ to 7.5 $( \pm 1.5) \%(P=0.006)$ (Fig. 2). In the intervention group, there was no significant difference between HbAlc at baseline, $7.3( \pm 1.3) \%$, and after 36 months, 7.2 $( \pm 0.7) \%(P=0.6)$ (Fig. 2). For the levels of HbAlc at baseline and during follow-up, see Table 2 and Fig. 2. The differences between the groups in absolute levels of $\mathrm{HbAlc}$ were not significant either at baseline or after 12 , 24 or 36 months. The levels of HbAlc were not influenced by age, gender, BMI, antibody prevalences or titres or C-peptide levels.

Table 2 Levels of glucagon-stimulated C-peptide ( $\mathrm{nmol} / \mathrm{l})$ and HbAlc (\%, DCCT standard), for all the participants and groups.

\begin{tabular}{|c|c|c|c|c|c|c|c|c|c|}
\hline & \multicolumn{3}{|c|}{ All } & \multicolumn{3}{|c|}{ Intervention group } & \multicolumn{3}{|c|}{ Control group } \\
\hline & Mean \pm S.D. & Min & Max & Mean \pm s.D. & Min & Max & Mean \pm s.D. & Min & Max \\
\hline C-peptide baseline & $1.45 \pm 0.8$ & 0.29 & 3.4 & $1.2 \pm 0.7$ & 0.29 & 3.0 & $1.7 \pm 0.9$ & 0.65 & 3.4 \\
\hline C-peptide 12 months & $1.35 \pm 0.9$ & 0.00 & 3.4 & $1.0 \pm 0.7$ & 0.0 & 3.3 & $1.7 \pm 0.9$ & 0.53 & 3.4 \\
\hline C-peptide 24 months & $1.17 \pm 0.8$ & 0.00 & 3.6 & $0.80 \pm 0.6$ & 0.0 & 1.8 & $1.5 \pm 0.9$ & 0.37 & 3.6 \\
\hline C-peptide 36 months & $0.99 \pm 0.8$ & 0.00 & 3.6 & $0.73 \pm 0.6$ & 0.0 & 2.2 & $1.3 \pm 0.9$ & 0.32 & 3.6 \\
\hline HbAlc baseline & $7.2 \pm 1.3$ & 5.2 & 10.1 & $7.3 \pm 1.3$ & 5.6 & 10.1 & $7.0 \pm 1.3$ & 5.2 & 9.5 \\
\hline HbAlc 12 months & $6.9 \pm 1.2$ & 5.2 & 10.9 & $7.1 \pm 1.0$ & 5.2 & 8.5 & $6.7 \pm 1.4$ & 5.4 & 10.9 \\
\hline HbAlc 24 months & $7.1 \pm 1.2$ & 5.1 & 9.3 & $7.4 \pm 1.0$ & 5.7 & 9.0 & $6.8 \pm 1.3$ & 5.1 & 9.3 \\
\hline HbAlc 36 months & $7.3 \pm 1.1$ & 5.3 & 9.8 & $7.2 \pm 0.7$ & 5.8 & 8.3 & $7.5 \pm 1.5$ & 5.3 & 9.8 \\
\hline
\end{tabular}



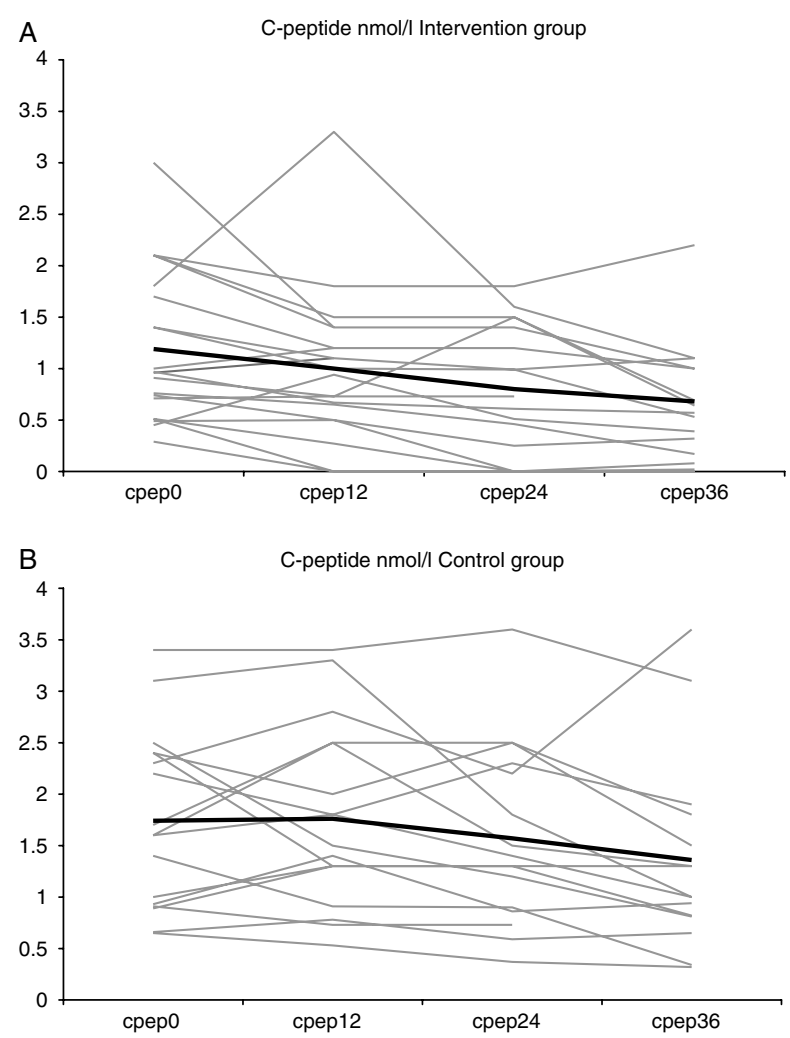

Figure 1 ( $A$ and $B$ ) C-peptide (nmol/l) for individual LADA subjects, in grey, and mean for the group, in black, at baseline and after 12, 24 and 36 months. The mean decline in C-peptide during the study was the same in both the groups, $r=0.174$ and 0.174 (NS).

\section{Autoimmunity}

At baseline, prevalences of GADAb were $94 \%$, ICA $67 \%$, $72 \%$ had both antibodies, $22 \%$ GADAb only and $6 \%$ only ICA, with no significant differences between the two treatment groups. Of the 32 patients whose IA-2A status was known, $7(22 \%)$ were positive, all of them were also positive to GADAb and all but one was positive to ICA, meaning that $75 \%$ of all were positive to at least two antibodies.

At baseline, mean indexes of GADAb were 0.78 $( \pm 0.39)$ in I, $0.78( \pm 0.48)$ in C (NS) and mean ICA titres were $29.4( \pm 40)$ in I, $72.4( \pm 119)$ JDF-U in C (NS). At baseline, there were no significant differences in the prevalences of any of the three antibodies between the two treatment groups or between genders, different ages, duration of diabetes before study start or levels of BMI or HbAlc. Neither were there any significant differences between the groups in titres of GADAb or ICA after 12, 24 or 36 months. The titres of GADab or ICA were not related to patient age, gender, BMI, diabetes duration, treatment or HbAlc at baseline or during the follow-up. C-peptide at baseline or 36 months was not influenced by baseline titre of GADAb, ICA or IA-2A.

\section{Adverse events}

No episodes of major hypoglycaemia were reported for any of the patients, and only a few minor ones.

Mean weight at baseline was $77.4( \pm 14.5$, range $57.8-110) \mathrm{kg}$ in group I, and $83.0( \pm 17.8$, range $50.8-117) \mathrm{kg}$ in group C (NS); at end-of-study 79.3 $( \pm 12.4,57.7-101) \mathrm{kg}$ in $\mathrm{I}, 82.3( \pm 14.8$, range 50.4-115) $\mathrm{kg}$ in C (NS). Mean weight change during the study was 2.5 ( \pm 4.8 , range -8.8 to +9.3$) \mathrm{kg}$ in I; $-1.0( \pm 10.5$, range -27.3 to +16.4$) \mathrm{kg}$ in $\mathrm{C}(\mathrm{NS})$.

\section{Three-group analysis and ever- versus never-insulin treated}

For the three groups, those treated with insulin from baseline, those never treated with insulin and those who were originally treated with $\operatorname{diet} \pm \mathrm{OHA}$, but had to start insulin treatment during the study, the influences of age, BMI, HbAlc, diabetes duration before study start or antibody titres were analysed, with no significant findings except for the influence of $\mathrm{CpO}$ on $\mathrm{Cp} 36$. The tests for all the relevant parameters were also carried out with the 37 patients divided into groups of everversus never-insulin treated (during the study), again with no significant results $(P=0.12-0.87)$, apart from the significant influence of $\mathrm{Cp} 0$ on $\mathrm{Cp} 36(\mathrm{P}<0.0001)$.

\section{Discussion}

Few prospective intervention studies have been conducted in LADA patients and there is still no general agreement on the best treatment aimed to preserve $\beta$-cell function $(5-7,16)$. There has not been any

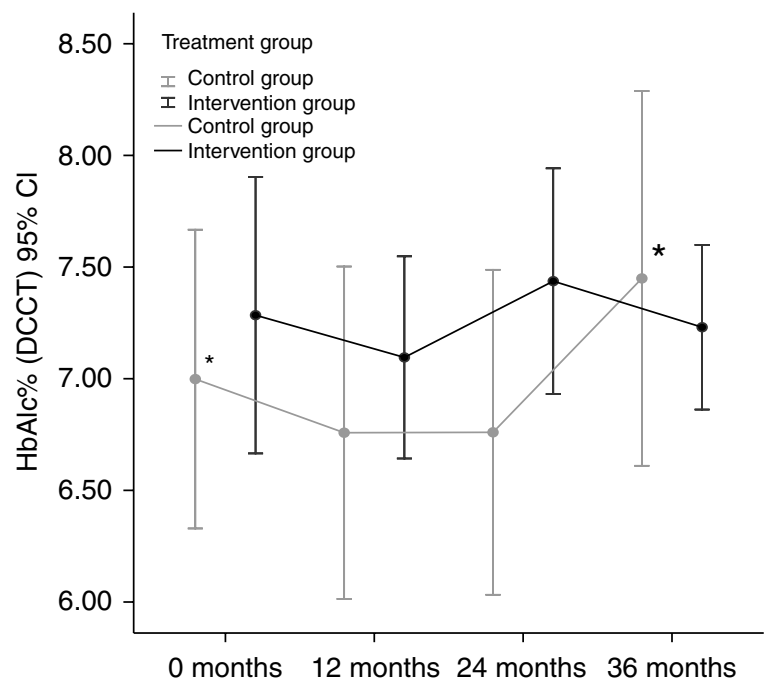

Figure 2 Mean HbAlc levels (\%, DCCT standard) for the two LADA groups during 36 months. ${ }^{*}{ }^{*}$ The asterisks indicate that the increase of $0.5 \%$ in $\mathrm{HbAlc}$ from baseline to 36 months within the control group is significant. 
general consensus definition of LADA, which complicates comparisons and pooling of results. The most common denominators are adult age, positivity to at least one pancreatic autoantibody, and non-insulin dependency at diagnosis (4). Age, BMI, duration of diabetes and of insulin independency, which of the antibodies that were analysed, GADAb titres and the expression of the essential outcome variable C-peptide vary $(2,4,5,28-30)$. A Cochrane review also noted the heterogeneity between studies, and the conclusion about early insulin treatment was uncertain (5). Our study included patients aged $\geq 30$ years, non-insulin dependent at the times of diagnosis and inclusion and positive to at least one pancreatic autoantibody, for $75 \%$ two antibodies, thereby fulfilling the main criteria for LADA (4). The results of the study indicated that none of the baseline parameters, except initial C-peptide level, significantly influenced the outcome, eliminating the importance of several criteria in comparisons with other studies. In other studies, patients aged $>65$ years have often been excluded, but LADA exists also in these older age groups (11).

The decline in residual $\beta$-cell function was progressive for the majority of our LADA patients, as is usual in autoimmune diabetes $(4,8,13,16)$. We observed great variation in the rates and magnitudes of $\beta$-cell loss between patients and between different time periods during the study, with no consistent patterns. Mechanisms such as more step-wise losses due to, for instance, partial remissions might explain this (15). The decline in C-peptide was irrespective of age, gender, BMI, antibody titres, HbAlc or treatment modality. The lack of influence of BMI, age, diabetes duration and baseline $\mathrm{HbAlc}$ on disease progression was also seen in a noninterventional observation study of LADA that followed 13 Ab-positive patients by stimulated C-peptide for 2 years (16).

Similar to UKPDS, we found no association between GADAb levels and disease progress (31), in contrast to observational studies that described this $(30,32)$. We could not, in a number of regression analyses, define any other factor besides $\mathrm{CpO}$ that significantly influenced the level of $\mathrm{Cp} 36$. The significance of initial C-peptide level was also demonstrated in a large Swedish study of new-onset 15-34 year olds and in the Tokyo intervention study $(28,33)$. The length of our study may explain that some patients with initially higher levels of $\mathrm{C}$-peptide, overrepresented in the control group, by 36 months had not yet lost enough $\beta$-cell function to be clinically insulin dependent. Some antibody-positive patients were described to take up to 12 years to become insulin dependent, but practically all eventually did (34).

A significant beneficial effect of early insulin treatment on the preservation of $\beta$-cell function could not be demonstrated, but level of HbAlc after 36 months was better preserved in the insulin treated, in keeping with observations by Chaillous et al. (16) in a smaller group of antibody-positive patients. Incidentally, the shape of the curve of the development of HbAlc levels over time for the conventionally treated group in our study had a likeness to that observed in the UKPDS (35).

Our study, as most prospective intervention studies of LADA, was not large. The Tokyo study, with 60 patients, found a preference for insulin treatment versus SU, possibly due to the differences in treatment, but longer duration of diabetes, up to 5 years without insulin before inclusion, rendering a selection of patients with better endogenous insulin production from the start, would have excluded those who progressed earlier to insulin dependence, so the trial population differed from ours (28). Baseline level of C-peptide was an important independent predictor of the ability to preserve a sufficient amount of C-peptide over time, just as in our study.

Many reports end with a general recommendation of insulin treatment in LADA, but the evidence has not been compelling, as concluded by the 2007 Cochrane review, which scrutinised seven insulin intervention studies in LADA, two insulin versus SU, the rest insulin alone versus different combinations of insulin + OHA (5). UKPDS recorded HbAlc, weight and treatment, randomised to insulin versus SU, and found that $60 \%$ of the SU treated were insulin dependent after 2 years (36). One conclusion was that SU might promote insulin dependency and apart from not recommending SU the Cochrane review found no preference for any special type of treatment for the LADA group (5). In our study after 3 years, $65 \%$ of the conventionally treated patients were not yet treated with insulin. In contrast to both UKPDS and the Tokyo study, only $30 \%$ of our control patients were treated with SU, which could be of importance for $\beta$-cell function. In another study, of 54 patients in four groups, the insulin treated, all with low $\mathrm{FCP}, \leq 0.3 \mathrm{nmol}$, received either insulin alone or combined with rosiglitazone (RGZ), and the OHA treated, all with FCP $>0.3 \mathrm{nmol} / \mathrm{l}$, received SU or RGZ (29). The results indicated that all who received RGZ better preserved their $\beta$-cell function.

\section{Further considerations}

To our knowledge, this study is the first prospective controlled European intervention study of treatment in LADA. Differences in defining the LADA population regarding age, diabetes duration before start of intervention, antibody prevalences and GADAb titres, BMI and, not least, baseline levels of C-peptide, if available, have contributed to difficulties in interpreting and comparing the results of the few existing LADA intervention studies $(4,5,28,29,37)$. In this study, none of these factors, except baseline level of C-peptide, significantly affected the outcome. The similar findings also seen in trials of classical type 1 diabetes and of prevention of autoimmune diabetes in high-risk 
individuals substantiate the observation of the influence of initial level of C-peptide on outcome level $(38,39)$.

We found a significantly better preservation of metabolic control in the early insulin treated. We also saw a non-significant OR favouring insulin treatment for preservation of $\beta$-cell function, indicating the possibility that a larger study population and/or a longer period of follow-up might demonstrate significant preference for early insulin treatment also regarding $\beta$-cell function.

\section{Conclusions}

This study indicated that early insulin treatment in LADA patients lead to better preservation of level of metabolic control, and that it was safe and well tolerated. It could not significantly confirm better preservation of $\beta$-cell function. The decline in C-peptide was progressive irrespective of age, gender, BMI, HbAlc levels and antibody titres. Only baseline level of C-peptide significantly influenced C-peptide level after 3 years. Further studies exploring the best treatment of LADA patients are warranted.

\section{Declaration of interest}

M Landin-Olsson has received a part-time professorship sponsored by Novo-Nordisk Scandinavia. The other authors have no dualities of interest in relation to this article.

\section{Funding}

The work was financed by the Healthcare Regions of Skane and Kronoberg, Southern Sweden; Lund University funding of clinical research (ALF); and the Swedish Council of Medical Research.

\section{Acknowledgements}

The authors thank diabetes nurses and physicians in the regions of Kronoberg and Lund, and the patients themselves; Anna Lindgren, $\mathrm{PhD}$, Department of Statistics, Mathematical Institute and Per Nyberg, $\mathrm{PhD}$, The Faculty of Medicine, both at Lund University for statistical advice; and Asst Prof. Anders Isaksson, Department of Clinical Chemistry, Lund University Hospital for analyses of C-peptide.

\section{References}

1 Landin-Olsson M, Nilsson KO, Lernmark A \& Sundkvist G. Islet cell antibodies and fasting C-peptide predict insulin requirement at diagnosis of diabetes mellitus. Diabetologia 199033 561-568. (doi:10.1007/BF00404145)

2 Turner R, Stratton I, Horton V, Manley S, Zimmet P, Mackay I, Shattock M, Bottazzo G \& Holman R. UKPDS 25: autoantibodies to islet-cell cytoplasm and glutamic acid decarboxylase for prediction of insulin requirement in type 2 diabetes. Lancet $19973 \mathbf{3 0}$ 1288-1293. (doi:10.1016/S0140-6736(97)03062-6)

3 Landin-Olsson M. Latent autoimmune diabetes in adults. Annals of the New York Academy of Sciences 2002958 112-116. (doi:10. 1111/j.1749-6632.2002.tb02953.x)
4 Fourlanos S, Dotta F, Greenbaum CJ, Palmer JP, Rolandsson O, Colman PG \& Harrison LC. Latent autoimmune diabetes in adults (LADA) should be less latent. Diabetologia 200548 2206-2212. (doi:10.1007/s00125-005-1960-7)

5 Brophy S, Brunt H, Davies H, Mannan S \& Williams R. Interventions for latent autoimmune diabetes (LADA) in adults. Cochrane Database of Systematic Reviews, 2007 CD006165. (doi:10. 1002/14651858.CD006165.pub2)

6 Cernea S, Buzzetti R \& Pozzilli P. Beta-cell protection and therapy for latent autoimmune diabetes in adults. Diabetes Care 200932 (Supplement 2) S246-S252. (doi:10.2337/dc09-S317)

7 Naik RG, Brooks-Worrell BM \& Palmer JP. Latent autoimmune diabetes in adults. Journal of Clinical Endocrinology and Metabolism 200994 4635-4644. (doi:10.1210/jc.2009-1120)

8 Tsai EB, Sherry NA, Palmer JP \& Herold KC. The rise and fall of insulin secretion in type 1 diabetes mellitus. Diabetologia 200649 261-270. (doi:10.1007/s00125-005-0100-8)

9 Seissler J. Latent (slowly progressing) autoimmune diabetes in adults. Current Diabetes Reports 20088 94-100. (doi:10.1007/ s11892-008-0018-x)

10 Krolewski AS, Warram JH, Rand LI \& Kahn CR. Epidemiologic approach to the etiology of type I diabetes mellitus and its complications. New England Journal of Medicine $1987 \mathbf{3 1 7}$ 1390-1398. (doi:10.1056/NEJM198711263172206)

11 Thunander M, Petersson C, Jonzon K, Fornander J, Ossiansson B, Torn C, Edvardsson S \& Landin-Olsson M. Incidence of type 1 and type 2 diabetes in adults and children in Kronoberg, Sweden. Diabetes Research and Clinical Practice $2008 \mathbf{8 2}$ 247-255. (doi:10. 1016/j.diabres.2008.07.022)

12 Neu A, Hofer SE, Karges B, Oeverink R, Rosenbauer J \& Holl RW. Ketoacidosis at diabetes onset is still frequent in children and adolescents: a multicenter analysis of 14,664 patients from 106 institutions. Diabetes Care 200932 1647-1648. (doi:10.2337/ dc09-0553)

13 Stenstrom G, Gottsater A, Bakhtadze E, Berger B \& Sundkvist G. Latent autoimmune diabetes in adults: definition, prevalence, betacell function, and treatment. Diabetes 200554 (Supplement 2) S68-S72. (doi:10.2337/diabetes.54.suppl_2.S68)

14 Scholin A, Berne C, Schvarcz E, Karlsson FA \& Bjork E. Factors predicting clinical remission in adult patients with type 1 diabetes. Journal of Internal Medicine 1999245 155-162. (doi:10.1046/j. 1365-2796.1999.00426.x)

15 Atkinson MA. Thirty years of investigating the autoimmune basis for type 1 diabetes. Diabetes $2005 \mathbf{5 4} 1253-1263$. (doi:10.2337/ diabetes.54.5.1253)

16 Chaillous L, Bouhanick B, Kerlan V, Mathieu E, Lecomte P, Ducluzeau PH, Delamaire M, Sonnet E, Maugendre D, Marechaud R, Rohmer V, Sai P \& Charbonnel B. Clinical and metabolic characteristics of patients with latent autoimmune diabetes in adults (LADA): absence of rapid beta-cell loss in patients with tight metabolic control. Diabetes and Metabolism 201036 64-70. (doi:10.1016/j.diabet.2009.07.004)

17 Gotfredsen CF, Buschard K \& Frandsen EK. Reduction of diabetes incidence of BB Wistar rats by early prophylactic insulin treatment of diabetes-prone animals. Diabetologia $1985 \quad 28$ 933-935. (doi:10.1007/BF00703140)

18 Atkinson MA, Maclaren NK \& Luchetta R. Insulitis and diabetes in NOD mice reduced by prophylactic insulin therapy. Diabetes 1990 39 933-937. (doi:10.2337/diabetes.39.8.933)

19 Kobayashi T, Nakanishi K, Murase T \& Kosaka K. Small doses of subcutaneous insulin as a strategy for preventing slowly progressive beta-cell failure in islet cell antibody-positive patients with clinical features of NIDDM. Diabetes 199645 622-626. (doi:10.2337/diabetes.45.5.622)

20 Palmer JP, Fleming GA, Greenbaum CJ, Herold KC, Jansa LD, Kolb H, Lachin JM, Polonsky KS, Pozzilli P, Skyler JS \& Steffes MW. C-peptide is the appropriate outcome measure for type 1 diabetes clinical trials to preserve beta-cell function: report of an ADA workshop, 21-22 October 2001. Diabetes 200453 250-264. (doi:10.2337/diabetes.53.1.250) 
21 Steffes MW, Sibley S, Jackson M \& Thomas W. Beta-cell function and the development of diabetes-related complications in the diabetes control and complications trial. Diabetes Care 200326 832-836. (doi:10.2337/diacare.26.3.832)

22 Nathan DM, Cleary PA, Backlund JY, Genuth SM, Lachin JM, Orchard TJ, Raskin P \& Zinman B. Intensive diabetes treatment and cardiovascular disease in patients with type 1 diabetes. New England Journal of Medicine 2005353 2643-2653. (doi:10.1056/ NEJMoa052187)

23 Nordwall MA, Arnqvist HJ, Bojestig M \& Ludvigsson J. Good glycemic control remains crucial in prevention of late diabetic complications - the Linkoping Diabetes Complications Study. Pediatric Diabetes 200810 168-176. (doi:10.1111/j.1399-5448. 2008.00472.x)

24 Picardi A \& Pozzilli P. Dynamic tests in the clinical management of diabetes. Journal of Endocrinological Investigation 2003 26 99-106.

25 Verge CF, Stenger D, Bonifacio E, Colman PG, Pilcher C, Bingley PJ \& Eisenbarth GS. Combined use of autoantibodies (IA-2 autoantibody, GAD autoantibody, insulin autoantibody, cytoplasmic islet cell antibodies) in type 1 diabetes: Combinatorial Islet Autoantibody Workshop. Diabetes 199847 1857-1866. (doi:10. 2337/diabetes.47.12.1857)

26 Bingley PJ, Bonifacio E \& Mueller PW. Diabetes Antibody Standardization Program: first assay proficiency evaluation. Diabetes 200352 1128-1136. (doi:10.2337/diabetes.52.5.1128)

27 Hoelzel W, Weykamp C, Jeppsson JO, Miedema K, Barr JR, Goodall I, Hoshino T, John WG, Kobold U, Little R, Mosca A, Mauri P, Paroni R, Susanto F, Takei I, Thienpont L, Umemoto M \& Wiedmeyer HM. IFCC reference system for measurement of hemoglobin A1c in human blood and the national standardization schemes in the United States, Japan, and Sweden: a methodcomparison study. Clinical Chemistry 200450 166-174. (doi:10. 1373/clinchem.2003.024802)

28 Maruyama T, Tanaka S, Shimada A, Funae O, Kasuga A, Kanatsuka A, Takei I, Yamada S, Harii N, Shimura H \& Kobayashi T. Insulin intervention in slowly progressive insulindependent (type 1) diabetes mellitus. Journal of Clinical Endocrinology and Metabolism 200893 2115-2121. (doi:10. 1210/jc.2007-2267)

29 Yang Z, Zhou Z, Li X, Huang G \& Lin J. Rosiglitazone preserves islet beta-cell function of adult-onset latent autoimmune diabetes in 3 years follow-up study. Diabetes Research and Clinical Practice 2009 83 54-60. (doi:10.1016/j.diabres.2008.09.044)

30 Radtke MA, Midthjell K, Nilsen TI \& Grill V. Heterogeneity of patients with latent autoimmune diabetes in adults: linkage to autoimmunity is apparent only in those with perceived need for insulin treatment: results from the Nord-Trondelag Health (HUNT) study. Diabetes Care 200932 245-250. (doi:10.2337/ dc08-1468)

31 Desai M, Cull CA, Horton VA, Christie MR, Bonifacio E, Lampasona V, Bingley PJ, Levy JC, Mackay IR, Zimmet P,
Holman RR \& Clark A. GAD autoantibodies and epitope reactivities persist after diagnosis in latent autoimmune diabetes in adults but do not predict disease progression: UKPDS 77 . Diabetologia 200750 2052-2060. (doi:10.1007/s00125-0070745-6)

32 Lohmann T, Kellner K, Verlohren HJ, Krug J, Steindorf J, Scherbaum WA \& Seissler J. Titre and combination of ICA and autoantibodies to glutamic acid decarboxylase discriminate two clinically distinct types of latent autoimmune diabetes in adults (LADA). Diabetologia 200144 1005-1010. (doi:10.1007/ s001250100602)

33 Jensen RA, Gilliam LK, Torn C, Landin-Olsson M, Karlsson FA, Palmer JP, Kockum I, Akesson K, Lernmark B, Lynch K, Breslow N \& Lernmark A. Multiple factors affect the loss of measurable C-peptide over 6 years in newly diagnosed 15- to 35-year-old diabetic subjects. Journal of Diabetes and its Complications 200721 205-213. (doi:10.1016/j.jdiacomp.2006.01.004)

34 Borg H, Gottsater A, Fernlund P \& Sundkvist G. A 12-year prospective study of the relationship between islet antibodies and beta-cell function at and after the diagnosis in patients with adultonset diabetes. Diabetes 200251 1754-1762. (doi:10.2337/ diabetes.51.6.1754)

35 UK Prospective Diabetes Study (UKPDS) Group. Intensive bloodglucose control with sulphonylureas or insulin compared with conventional treatment and risk of complications in patients with type 2 diabetes (UKPDS 33). Lancet 1998352 837-853. (doi:10. 1016/S0140-6736(98)07019-6)

36 Davis TM, Wright AD, Mehta ZM, Cull CA, Stratton IM, Bottazzo GF, Bosi E, Mackay IR \& Holman RR. Islet autoantibodies in clinically diagnosed type 2 diabetes: prevalence and relationship with metabolic control (UKPDS 70). Diabetologia $2005 \mathbf{4 8}$ 695-702. (doi:10.1007/s00125-005-1690-x)

37 Li X, Liao L, Yan X, Huang G, Lin J, Lei M, Wang X \& Zhou Z. Protective effects of 1-alpha-hydroxyvitamin D3 on residual betacell function in patients with adult-onset latent autoimmune diabetes (LADA). Diabetes/Metabolism Research and Reviews 2009 25 411-416. (doi:10.1002/dmrr.977)

38 Akirav E, Kushner JA \& Herold KC. Beta-cell mass and type 1 diabetes: going, going, gone? Diabetes 200857 2883-2888. (doi:10.2337/db07-1817)

39 Schatz D, Cuthbertson D, Atkinson M, Salzler MC, Winter W, Muir A, Silverstein J, Cook R, Maclaren N, She JX, Greenbaum C \& Krischer J. Preservation of C-peptide secretion in subjects at high risk of developing type 1 diabetes mellitus - a new surrogate measure of non-progression? Pediatric Diabetes 20045 72-79. (doi:10.1111/j.1399-543X.2004.00047.x)

Received 14 November 2010

Accepted 18 November 2010 